\title{
Increasing Learning Achievement In Theme 4 Through Discovery Learning Method With Animated Image Media
}

\author{
Yunita Putriati \\ SD Muhammadiyah 8 Surakarta \\ yunitaputriati@gmail.com
}

\section{Article History}

accepted $14 / 11 / 2020$

approved $21 / 11 / 2020$

published 26/11/2020

\begin{abstract}
The purpose of this study was to increase student learning achievement on the two-dimensional figure material of my family theme (my family tree). This research is a classroom action research (PTK) which was conducted in 2 cycles, each cycle consisting of planning, implementation, observation, and reflection stages. The subjects of this study were the first grade students of SD Muhammadiyah 8 Jagalan, Jebres District, Surakarta Regency in the academic year 2020/2021, totaling 27 students. Data collection techniques using observation, interviews, and tests. Data analysis includes data reduction, data presentation, and drawing conclusions. Research shows that the Animated Image Media can increase student learning achievement on the two-dimensional figure material of my family theme (my family tree) in grade I SD Muhammadiyah 8 Jagalan, Jebres District, Surakarta Regency in the academic year $2020 / 2021$ as evidenced by the percentage of completeness of learning achievement in cycle I of $55.6 \%$ to $85.2 \%$ in cycle II
\end{abstract}

Keywords: learning achivement, discovery learning method, animated image media

\begin{abstract}
Abstrak
Tujuan penelitian ini adalah meningkatkan hasil belajar siswa pada materi Bangun Datar dalam tema Keluargaku (Silsilah Keluargaku). Penelitian ini merupakan penelitian tindakan kelas (PTK) yang dilaksanakan dalam 2 siklus, setiap siklus terdiri dari tahap perencanaan, pelaksanaan, observasi, dan refleksi. Subjek penelitian ini adalah siswa kelas I SD Muhammadiyah 8 Jagalan, Kecamatan Jebres, Kota Surakarta tahun pelajaran 2020/2021 yang berjumlah 27 siswa. Teknik pengumpulan data menggunakan observasi dan tes. Analisis data meliputi reduksi data, penyajian data, dan penarikan kesimpulan. Penelitian menunjukkan bahwa media Gambar Animasi dapat meningkatkan prestasi belajar siswa pada materi bangun Datar dalam tema Keluargaku (Silsilah Keluargaku) di kelas I SD Muhammadiyah 8 Jagalan, Kecamatan Jebres, Kota Surakarta tahun pelajaran 2020/2021 dibuktikan dengan prosentase ketuntasan hasil belajar pada siklus I sebesar $55.6 \%$ menjadi $85.2 \%$ pada siklus II
\end{abstract}

Kata kunci: prestasi belajar, metode discovery learning, media gambar animasi

Social, Humanities, and Education Studies (SHEs): Conference Series https://jurnal.uns.ac.id/shes

p-ISSN 2620-9284

e-ISSN 2620-9292 


\section{PENDAHULUAN}

Kejadian luar biasa yang melanda dunia pada akhir tahun 2019 yang muncul dari Wuhan, yaitu Corona Virus Disease 2019 (Covid-19) telah melumpuhkan semua aspek kehidupan, baik aspek kesehatan, sosial, ekonomi, tidak terkecuali dunia pendidikan. Pengertian Virus corona dari beberapa pendapat, yaitu "Virus corona atau severe acute respiratory syndrome coronavirus 2 (SARS-CoV-2) adalah virus yang menyerang sistem pernapasan." (Yezli \& Khan, 2020 (Pramudya, 2020)). Di Indonesia pun tidak terhindar dari penyebaran Corona Virus Disease 2019 (Covid-19) mulai muncul kasus pada akhir bulan Februari 2020. Dengan adanya fakta bahwa di Indonesia terdapat yang positif terinfeksi COVID-19 pertama kali dan telah diumumkan oleh Pemerintah, secara psikologis telah menyerang sendi-sendi kehidupan.

Sejak munculnya kasus pertama, dan untuk pencegahan penyebaran COVID-19 tersebut, maka untuk penanganan Corona Virus Disease 2019 (Covid-19) di dunia pendidikan, Menteri Pendidikan dan Kebudayaan Republik Indonesia menerbitkan Surat Edaran Nomor: 36962/MPK.A/HK/2020, Tanggal 17 Maret 2020 Perihal Pembelajaran secara Daring dan Bekerja dari Rumah dalam Rangka Pencegahan Penyebaran Corona Virus Disease (COVID- 19).(Kementerian Pendidikan dan Kebudayaan Republik Indonesia, 2020). Selanjutnya diterbitkan kembali Surat Edaran Nomor 4 Tahun 2020 di lingkungan Kemendikbud tentang Pelaksanaan Kebijakan Pendidikan Dalam Masa Darurat Penyebaran Coronavirus Disease (COVID19).(Kementerian Pendidikan dan Kebudayaan, 2020) Perubahan kondisi yang mendadak di dunia pendidikan diharapkan tidak menghalangi jalannya proses pembelajaran. Rusaknya sumber daya manusia yaitu tunas bangsa, generasi muda adalah harga yang harus dibayar apabila proses pendidikan terhenti. Upaya mencegah pendemi ini supaya tidak tersebar luas, belajar dari rumah bagi pendidik dan peserta didik merupakan tindak lanjut dari anjuran pemerintah mulai dari social distancing sampai dengan physical Distancing. Pengertian social distancing adalah, "Social distancing artinya sesama individu harus menjaga jarak satu dengan yang lainnya." (Pramudya, 2020). Sehubungan dengan anjuran dari Pemerintah adanya penerapan social distancing sampai dengan physical Distancing, agar proses pembelajaran tetap berjalan dengan baik dan optilmal perlu dilakukan terobosan sebagai solusi di masa pandemi. Proses pembelajaran secara virtual atau Pembelajaran Jarak Jauh (PJJ) merupakan sebuah tuntutan sebagai solusi untuk menyesuaikan dengan situasi dan kondisi saat ini, dan siap tidak siap harus berlangsung.

Bagi sebagian pendidik proses pembelajaran jarak jauh merupakan suatu hal yang baru dan belum terbiasa. Fenomena pembelajaran jarak jauh saat ini membuat kerepotan bagi pendidik. Seorang pendidik saat ini dipaksa untuk menggunakan perangkat yang ada guna mendukung pendidikan secara virtual. Pemilihan media yang tepat dalam pembelajaran selama masa pendemi ini bertujuan untuk menghasilkan output yang baik dan disesuaikan dengan kebutuhan dan kondisi yang ada. Pembelajaran secara virtual yang menjadi tuntutan saat ini dapat menggunakan media daring.

Tantangan bagi pendidik pada masa pandemi ini adalah bagaimana mengupayakan dengan media daring agar proses pembelajaran dengan media daring dapat optimal dan tidak mengurangi esensi yang akan disampaikan oleh pendidik kepada peserta didik seperti pembelajaran tatap muka. Pembelajaran dengan media daring yang dilaksanakan secara optimal dengan harapan output yang dihasilkan juga akan maksimal, tidak menimbulkan kejenuhan, kebosanan baik dari pendidik maupun peserta didik, sehingga dalam kondisi belajar dari rumah tetap akan mencetak generasi yang unggul. Banyak media daring yang bisa digunakan saat ini baik melalui aplikasi Whatsapp, Whatsapp group, goggle form, dan youtube.

Peranan media pembelajaran sangat berpengaruh pada kegiatan pembelajaran. Kurangnya penggunaan media pembelajaran dalam kegiatan pembelajaran, terutama 
pada mata pelajaran matematika juga sangat berpengaruh pada motivasi belajar siswa. Untuk itu guru dituntut lebih kreatif dan inovatif dalam pembuatan media pembelajaran dengan tujuan agar motivasi belajar siswa lebih meningkat dengan adanya pengembangan media pembelajaran yang tepat. Jadi hasil belajar siswa akan lebih tinggi. Bicara tentang pengembangan media pembelajaran, tidak terpungkiri juga kita harus memikirkan bagaimana cara membuat media pembelajaran yang tepat dan inovatif. Dengan harapan bahwa penggunaan media akan mempercepat dan mempermudah pencapaian tujuan pembelajaran. Untuk itu kita sebagai guru harus bisa mengambangkan media pembelajaran dengan tepat, yaitu menciptakan media pembelajaran yang kreatif dan inovatif dengan memanfaatkan bahan-bahan yang ada di lingkungan sekitar.

Kenyataan yang ada di lapangan khususnya di tempat penelitian yaitu di SD Muhammadiyah 8, Kecamatan Jebres, Surakarta, proses pembelajaran matematika masih menggunakan pendekatan konvensioanal (ceramah) dan kurangnya penggunaan media pembelajaran oleh guru. Guru aktif dalam menjelaskan materi pelajaran sementara siswa hanyalah sebagai pendengar saja. Siswa kurang diikut sertakan dalam pengelolaan informasi, sehingga siswa tidak aktif dalam mengikuti kegiatan pembelajaran yang berlangsung, dan untuk itu motivasi belajar siswa menjadi rendah, ditandai dengan banyaknya siswa yang bermain sendiri dan bersenda gurau pada saat kegiatan pembelajaran berlangsung. Dalam proses pembelajaran guru terbatas hanya menekankan pada penanaman konsep pada diri siswa, tanpa memperdulikan apakah konsep-konsep yang telah diajarkan sudah dipahami oleh siswa itu sendiri.

Berdasarkan pengalaman yang saya peroleh dan hasil wawancara dengan teman sejawat selama mengajar di kelas rendah, utamanya kelas 1 SD Muhammadiyah 8 Kecamatan Jebres Surakarta, alasan guru kurang menggunakan media pembelajaran dalam proses pembelajaran dikarenakan kurangnya pemahaman guru tentang cara atau tahapan dalam mengembangkan media pembelajaran. Untuk itu peneliti mengembangkan media gambar animasi sebagai bahan tambahan referensi bagi guru dalam mengembangkan media pembelajaran khususnya media gambar untuk mata pelajaran matematika pada materi bangun datar untuk meningkatkan konsentrasi siswa, keaktifan siswa, motivasi siswa dalam mengikuti pelajaran dan terutama meningkatkan hasil belajar siswa, pada mata pelajaran matematika.

Dari uraian di atas maka peneliti tertarik untuk melakukan penelitian pada kelas 1 di SD Muhammadiyah 8 Kecamatan Jebres Surakarta dengan menggunakan hasil pengembangan media animasi gambar untuk meningkatkan hasil belajar siswa pada materi bangun datar muatan pelajaran matematika dalam tema keluargaku.

\section{METODE}

Penelitian ini merupakan penelitian tindakan kelas yang dilaksanakan dalam 2 siklus, setiap siklus terdiri dari tahap perencanaan, pelaksanaan, observasi, dan refleksi. Penelitian ini dilakukan di kelas I SD Muhammadiyah 8 Jagalan, Kecamatan Jebres, Kota Surakarta, dengan jumlah 27 siswa terdiri dari 17 siswa laki-laki dan 10 siswa perempuan. Sumber data dalam penelitian ini adalah siswa kelas I SD Muhammadiyah 8 Jagalan dan teman sejawat sebagai observer selama pelaksanaan perbaikan pembelajaran. Data yang dikumpulkan adalah data kualitatif dan kuantitatif yang terdiri dari data kualitatif berupa data proses pembelajaran, data pemahaman siswa terhadap materi pembelajaran, dan data respon siswa terhadap penggunaan media pembelajaran. Sedangkan data kuantitatif berupa hasil pembelajaran berbentuk nilai tes formatif. Teknik pengumpulan data berupa observasi untuk mengamati aktifitas siswa dan guru selama proses pembelajaran daring, daftar permintaan akses link bahan ajar dan LKPD melalui email guru, dan tes formatif melalui link googleform untuk mengetahui tingkat penguasaan siswa terhadap materi pembelajaran menggunakan 
media gambar animasi. Data kualitatif akan diolah dalam bentuk paparan narasi yang menggambarkan kualitas pembelajaran, sedangkan data kuantitatif akan diolah melalui analisis deskriptif atau analisis data yang dilakukan berdasarkan tes formatif dari siklus pertama dan siklus kedua pembelajaran. Prosedur pelaksanaan PTK dilaksanakan dalam satu siklus perbaikan.

\section{HASIL DAN PEMBAHASAN}

Berdasarkan analisis hasil penelitian yang telah diuraikan maka pembahasan pada penelitian ini sebagai berikut :

Tabel 1. Rekapitulasi Prestasi Belajar Siswa

\begin{tabular}{|c|c|c|c|c|c|c|}
\hline \multirow[t]{2}{*}{ No } & \multirow{2}{*}{$\begin{array}{c}\text { Kegiatan } \\
\text { perbaikan } \\
\text { pembelajaran }\end{array}$} & \multirow{2}{*}{$\begin{array}{c}\text { Jumlah } \\
\text { siswa }\end{array}$} & \multicolumn{2}{|c|}{ Tuntas belajar } & \multicolumn{2}{|c|}{ Belum tuntas belajar } \\
\hline & & & Jumlah & Prosentase & Jumlah & Prosentase \\
\hline 1 & Siklus 1 & 27 & 15 & $55.6 \%$ & 12 & $44.4 \%$ \\
\hline 2 & Siklus 2 & 27 & 23 & $85.2 \%$ & 4 & $14.8 \%$ \\
\hline
\end{tabular}

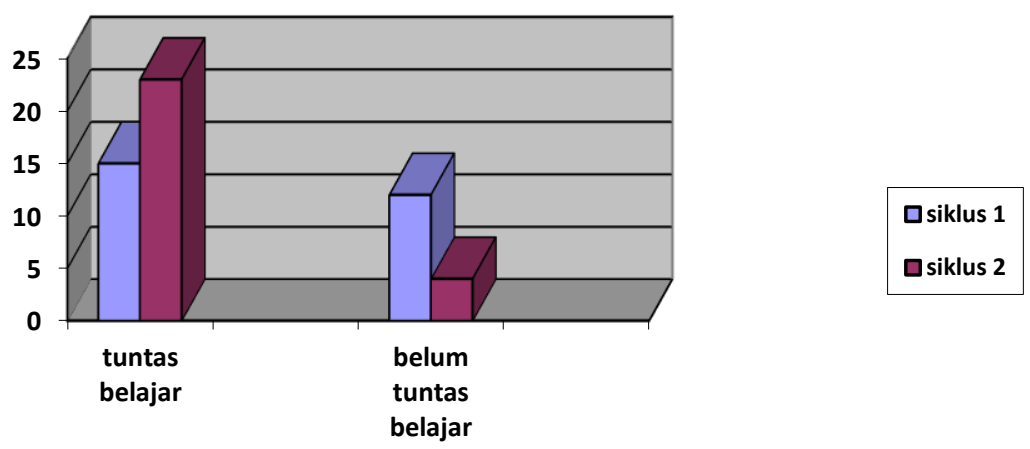

\section{Gambar 1. Rekapitulasi Peningkatan Prestasi Belajar Siswa}

Pada Siklus 1 nilai rata-rata kelas hanya mendapatkan 68.3 dan belum mendapat nilai lebih dari KKM yang sudah ditentukan dalam kelas yaitu 70 . Kemudian dilakukan perbaikan pada pembelajaran siklus 2 mendapatkan nilai rata-rata kelas 78.1, dari hasil nilai rata-rata tersebut artinya perbaikan pembelajaran mendapatkan peningkatan pada siklus 2. Pada Siklus 1, siswa yang tuntas belajar hanya 15 dari 27 siswa atau sebesar $55.6 \%$. Pada siklus 2, siswa yang tuntas belajar sebanyak 23 dari 27 siswa atau sebesar $85.2 \%$, ini menunjukkan bahwa perbaikan pembelajaran menggunakan metode discovery learning dengan gambar animasi bisa meningkatkan prosentase ketuntasan belajar siswa.

Tabel 2. Rekapitulasi Respon Siswa

\begin{tabular}{llcccc}
\hline No & $\begin{array}{c}\text { Perbaikan } \\
\text { pembelajaran }\end{array}$ & \multicolumn{2}{c}{$\begin{array}{c}\text { Media memudahkan } \\
\text { pemahaman materi }\end{array}$} & \multicolumn{2}{c}{ Prosentase } \\
\cline { 3 - 6 } & & Setuju & $\begin{array}{c}\text { Tidak } \\
\text { setuju }\end{array}$ & Setuju & $\begin{array}{c}\text { Tidak } \\
\text { setuju }\end{array}$ \\
\cline { 3 - 6 } & Siklus 1 & 14 & 13 & $51.9 \%$ & $48.1 \%$ \\
\hline 1 & Siklus 2 & 21 & 6 & $77.8 \%$ & $22.2 \%$ \\
\hline
\end{tabular}




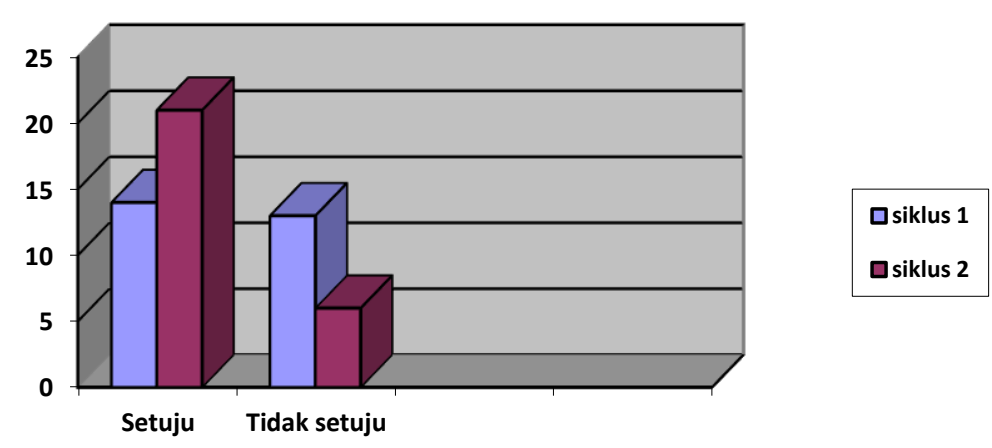

\section{Gambar 2. Rekapitulasi Respon Siswa}

Dari tabel di atas menunjukkan bahwa pada pembelajaran siklus 1, siswa yang setuju bahwa media gambar animasi dapat memahami materi bangun datar yaitu ada 14 siswa atau sebesar $51.9 \%$. Sedangkan 13 siswa atau sebesar $48.1 \%$ tidak setuju media gambar animasi dapat membantu memahami materi bangun datar. Pada pembelajaran siklus 2, siswa yang setuju media gambar animasi dapat membantu memahami materi bangun datar meningkat yaitu ada 21 siswa atau sebesar $77.8 \%$. Sedangkan 6 siswa atau sebesar $22.2 \%$ sampai dengan siklus ini tidak setuju media dapat membantu memahami materi pembelajaran bangun datar untuk menyusun silsilah keluarga. Artinya, pada siklus ini siswa yang paham terhadap materi menjadi bertambah sehingga prestasi belajar ada peningkatan dan menjadi lebih baik.

Berdasarkan beberapa data yang diperoleh peneliti di atas, yaitu terdapat peningkatan data jumlah dan prosentase ketuntasan belajar siswa dan respon siswa ketika materi pembelajaran disajikan menggunakan media gambar animasi dengan metode discovery learning, maka prestasi belajar dapat mengalami peningkatan dengan berbagai perbaikan pembelajaran baik itu melalui metode maupun media pembelajaran yang digunakan. Hal ini sesuai dengan teori yang dikemukakan oleh Syamil (2018) yaitu prestasi yang diperoleh siswa tidak datang dengan sendirinya. Diperlukan suatu cara atau metode yang dapat dilakukan oleh orang tua atau guru untuk meningkatkan prestasi belajar siswa.

Perbaikan pembelajaran pada siklus 2 ini dilakukan dengan menggunakan metode discovery learning dan menggunakan media pembelajaran gambar animasi, dimana sesuai metode ini akan menitikberatkan aktivitas siswa yang akan diarahkan untuk menemukan suatu konsep atau prinsip. Aktivitas dan respon siswa juga semakin meningkat terbukti dengan data respon penggunaan media gambar animasi, ini artinya siswa lebih mudah memahami materi bangun datar untuk menyusun silsilah keluarga dengan menyimak gambar animasi dibanding dengan pembelajaran pada siklus 1 dimana siswa hanya membaca materi melalui buku dan mendengarkan penjelasan guru. Menurut Hosnan (2014:282), discovery learning adalah suatu model untuk mengembangkan cara belajar aktif dengan menemukan sendiri, menyelidiki sendiri, maka hasil yang diperoleh akan setia dan tahan lama dalam ingatan. Melalui belajar penemuan, siswa juga bisa belajar berpikir analisis dan mencoba memecahkan sendiri masalah yang dihadapi.

Perbaikan pembelajaran berikutnya di siklus 2 adalah peneliti menggunakan media gambar animasi dalam menyajikan materi bangun datar untuk menyusun bagan silsilah keluarga, data prestasi belajar siswa terlihat meningkat dengan perbaikan ini. Hal ini senada dengan teori berikut, menurut Rusman (2010) manfaat secara umum, media dalam proses pembelajaran adalah memperlancar interaksi antara guru dengan siswa sehingga kegiatan pembelajaran akan lebih efektif dan efisien. Tetapi secara. lebih khusus ada beberapa manfaat media yang lebih rinci. 


\section{SIMPULAN}

Berdasarkan hasil analisis dari siklus pertama sampai siklus kedua, dapat disimpulkan bahwa penggunaan media gambar animasi dapat meningkatkan prestasi belajar matematika materi bangun datar dalam tema keluargaku (silsilah keluarga) pada siswa kelas I SD Muhammadiyah 8 Jagalan, Kecamatan Jebres, Kota Surakarta. Dampak penggunaan media gambar animasi yaitu mampu meningkatkan pemahaman materi pembelajaran sehingga prestasi belajar siswa meningkat pada mata pelajaran matemtika materi bangun datar dalam tema keluargaku (silsilah keluarga) pada siswa kelas I SD Muhammadiyah 8 Jagalan, Kecamatan Jebres, Kota Surakarta. Peneliti hendaknya menggunakan pendekatan dan metode yang sama untuk mengatasi permasalahan pembelajaran yang sama. Peneliti juga harus selalu menggunakan media pembelajaran yang menarik sehingga membantu memudahkan siswa memahami materi untuk mengatasi permasalahan pembelajaran yang sama.

\section{DAFTAR PUSTAKA}

Ahmad Tanzeh. 2011. Metode Penelitian Praktis. Yogyakarta: Teras

Arikunto, Suharsimi. 2010. Dasar-Dasar Evaluasi Pendidikan. Jakarta : Bumi Aksara

Asy Syamil (2018 April 04). Diakses dari http://asy-syaamil.com/cara-meningkatkanprestasi-belajar-pada-anak/

Azhar Arsyad, 2009. Media Pembelajaran. Jakarta : Raja Grafindo Persada.

Budiyono. 2009. Statistika untuk Penelitian. Surakarta : Sebelas Maret University Press Depdiknas. 2003. Undang-Undang RI No. 20 Tahun 2003. Sistematika Pendidikan Nasional. Jakarta: Citra Umbara.

Eggen, Paul dan Don Kauchak. 2012. Strategi dan Pembelajaran Edisi Keenam. Jakarta : Indeks.

Herdiansyah, Haris. 2012. Metodologi Penelitian Kualitatif. Jakarta: Salemba Humanika.

Heruman, 2007. Model Pembelajaran Matematika di Sekolah Dasar. Bandung : Remaja Rosdakarya.

Hosnan. 2014. Pendekatan Saintifik dan Kontekstual dalam Pembelajaran Abad 21. Bogor: Ghalia Indonesia.

Kemendikbud. 2013b. Materi Pelatihan Guru Implementasi Kurikulum 2013. Kemendikbud. Jakarta. $220 \mathrm{hlm}$..

Rusman. 2010. Model-model Pembelajaran. Bandung : Mulia Mandiri Press

Yezli \& Khan, 2020. Virus yang Menyerang Sistem Pernafasan. Jakarta : Rineka Cipta. 